\title{
The Coalition Government and employment rela- tions: accelerated neo-liberalism and the rise of employer-dominated voluntarism
}

Peter Scott and Steve Williams

\section{Résumé}

The Coalition Government's interventions in the field of UK employment relations represent a sustained attempt to shift further the balance of domestic employment law and workplace employment relations in favour of employers. The Government has deployed the alleged interests of small and medium sized employers, under conditions of recession and accelerated globalisation, to weaken some individual employment rights, including various long-standing protections. Suprisingly little internal dissension to such developments has been apparent within the Coalition. A 'Coalition effect' is detectable through the parallel promotion of 'fairness', most visible in a number of new measures to promote work-life balance. However, we argue that the overall impact on UK employment relations is a deliberate attempt to reduce employment rights and the role of law in the individual employment relationship, to weaken workers' ability to enforce remaining rights, and to strengthen the position of employers vis-a vis employees and government in the regulation of many aspects of the employment relationship.

Mots clés : employment relations, Coalition Government, employment law 


\section{Introduction}

In this chapter, we argue that the UK Coalition Government's policies in the field of employment relations represent a reassertion of a 'deinstitutionalised' neo-liberal approach, different in emphasis from that adopted by Labour between 1997-97. As with other policy areas, such as health and school-level education, a momentum is evident to use power gradually to roll back important elements of the post-World War Two settlement as a whole. Developing previous work on recent Conservative and Coalition policy prescriptions in this area (Williams and Scott, 2010, 2011), we argue that any limited trends towards social liberalism from either side of the Coalition, in opposition or in government, have been outweighed by the removal or attrition of employment relations institutions that attempt to act as guarantours of individual employment rights. Although a limited evidence base exists to support the necessity of many of the changes being undertaken, a comprehensive and multifaceted ideological web, based around the alleged interests of entrepreneurs and - predominantly small and medium sized - business has been spun to provide public justification for the direction of change that the Coalition is attempting. The overall intention is to return the UK to a greater voluntarism in employment relations; in the context of current political circumstances, however, this voluntarism is employerdominated rather than the subject of joint regulation between employers and employees. The Coalition Government has focused less explicitly than the 1979-97 Conservative administrations on the reform of trade unions and collective employment relations, although the Conservative side of the Coalition has begun to call for the resumption of reform here, particularly as the 2015 General Election draws closer.

We contend, in this chapter, that the overall impact of the Coalition's reforms is to weaken further the already parlous position, rights and security of UK workers. Employment relations can increasingly be likened to the simile of a colander: a structure is present, but it is beset with holes, through which much of the meaningful content of employment rights is gradually draining out. The apparently abiding corpus of workers' rights is dissipated in practice by increasing difficulty in enforcing them and in exercising 'voice'. These problems are occurring in the context of weakened legal underpinning, limited trade union influence, and government's wish to relinquish its own direct influence in setting employment standards, in deference to the vagaries of employers' prerogative to manage their firms as they consider best. As we will argue, this state of affairs has been enabled by a remarkable, and essentially ideological, confluence between those in positions of power within the 
Government; few overt disputes about employment relations policy have emerged, beyond differences of emphasis, at ministerial level, although this is partly due to most of the potentially politically divisive issues around European-derived employment rights having been sidelined until the expiry of the Coalition's term of office.

We first investigate the distinctiveness, in comparison to previous governments, of the Coalition's approach to the employment relations policy field. Second, we weigh up the respective merits of claims that Coalition policy represents a radical restructuring against an interpretation that change is more gradualist. Evidence allows support for an interpretation that combines both these views, largely because of the relatively indirect way that the Coalition has approached the process of achieving change. We review some of the main rhetorics the Coailtion has used to justify the need for reform. Finally, our overall evaluation of the Coalition's activity in this field suggests a subordination of employees' rights in the workplace to a weakened body of legal and collective remedies and to an idealistic reliance on the voluntary goodwill of enlightened employers.

\section{How distinctive is the Coalition's approach?}

We begin by analysing the extent to which Coalition policy towards employment relations displays elements of continuity or contrast with previous UK governments. As we will see, such a historical perspective requires us to look further back in time than one might expect. The 1979-97 Conservative governments provide an obvious source to seek possible continuities in policy themes with a Conservative-led Coalition government. The Coalition's various interventions into the field of UK employment relations intensify many of the themes encountered in the Thatcher / Major administrations' neo-liberal restructuring of this policy area, which is somewhat ironic, given David Cameron's tactical concern in opposition to distance his policies from the 'nasty party' image (Williams and Scott, 2010). Examples of policy continuities with the Thatcher and Major governments include the encouragement of a more flexible labour market, support for employee share ownership, particularly through Chancellor George Osborne's employee - shareholder scheme, further marketisation of the public sector and privatisation (notably, the plan to sell successive shares in Royal Mail). There has been continued gradual devolution of pay-setting in the public sector including, most recently, devolving to school level in England and Wales decisions on teachers' incremental progression through pay scales, based on teachers' performance rather than according to their length of service in 
pay settlements from September 2014 (Department for Education, 2013). As we discuss below, attacks on trade union rights within the workplace and the internal functioning and governance of trade unions have been a more muted feature of the Coalition than the 1979-97 Conservative governments, although the Conservative part of the Coalition has amplified this theme from late 2013, primarily for reasons of perceived electoral advantage.

Coalition policy also erodes or reverses some parts of Labour's 1997-2010 settlement for employment relations, which has been described as a 'liberal collectivist' inheritance (Grimshaw and Rubery, 2012) or as a limited, state-sponsored reinstitutionalisation of employee relations (Bach and Kessler, 2011). A totemic example is the reinstatement of the pre-1999 qualifying period for employees' right to claim unfair dismissal, extending this period from one year to two years. There are many further instances. They include the abolition of employment relations institutions such as the School Support Staff Negotiating Board, set up by Labour in 2009 to provide a national framework for the pay and conditions of administrative staff in schools, but abolished by January 2012. In England, codes of practice (the so-called Two Tier Codes) negotiated by Labour as part of the Warwick Agreement that prevented new recruits in outsourced public services from being offered inferior terms and conditions than equivalent staff transferred from the public sector have been successively withdrawn in public services controlled by Conservative Coalition ministers. The scope of the 2006 Transfer of Undertakings Regulations is to be tightened in proposals to be laid before Parliament in Dec 2013, which also incorporate the European Court of Justice's restrictive ruling in the Alemo-Herron vs. Parkwood Leisure Ltd. case (Labour Research, 2013).

A major Coalition theme has been to undermine the structures set up by Labour to oversee the promotion of equality and oppose discrimination. The influence of the Equality and Human Rights Commission (EHRC) has been weakened: its budget has been cut by $70 \%$ and its regional offices closed. A number of sections of one of Labour's final measures, the 2010 Equality Act (EqA), have either never been implemented or have been successively removed, including the proposed introduction of a 'socio-economic duty' to eliminate discrimination on grounds of social origin, Labour's proposal to permit individuals to take discrimination cases on multiple protected grounds, removal of employers' liability for harassment of staff by third parties, the removal of a requirement for English public sector employers to carry out equality impact assessments, a review in 2013 of the future of the EqA's Public Sector Equality Duty, and a proposal in the 2013 Deregulation Bill cur- 

which gives employment tribunals the power in discrimination cases to make wider recommendations that are applicable to a whole workforce rather than just to the complainant.

Perhaps more significant, we would argue, is evidence that some of the Coalition's actions attempt to undo elements of the post-World War Two industrial relations settlement that emerged relatively unscathed from the 1979-97 Conservative governments. Two obvious examples are significant restructuring of the post-1964 system for adjudicating on employment law disputes (Corby and Latreille, 2012), now known as Employment Tribunals, which are considered further below, and the reform of occupational pensions, particularly as these impact on public sector workers. The Agricultural Wages Board, set up by the Attlee Labour government to regulate pay and conditions for agricultural workers, was the only tripartite Wages Council to survive the 1979-97 Conservative administrations, but has been abolished in England and Wales from October 2013. Similarly, recurrent initiatives have been mooted to replace national bargaining within the public sector, a process that has been encouraged by governments since the inter-war era (Howell, 2005). Both the 1979-97 Conservative and 1997-2010 Labour governments toyed with ideas for more regionalised or localised substitutes for national bargaining. The Coalition's public consultation on this subject in 2012, following a number of reports from market liberal think-tanks, demonstrated little support for the idea, even from employers; and thus the government has turned towards other ideas for relating public sector pay more closely to performance (Bach and Stroleny, 2013, 344).

\section{How radical is the reform process?}

The degree of legislative freedom of coalition governments may be regarded in two ways. First, coalitions may be able to use their parliamentary majority and lack of external opposition to push through radical changes normally unattainable. Alternatively, it may be argued that such governments are unstable alliances requiring frequent negotiation between parties with competing interests and ideologies, thus limiting their freedom of manoeuvre to pursue controversial policies. To what extent can these perspectives be applied to the UK Coalition Government as regards the field of employment relations? It is unlikely that the above views are entirely mutually exclusive, and it is certainly possible to garner evidence to bolster both arguments.

On one hand, the Coalition's attempted changes have been characterised as a rapid, far-reaching ideological attack on organised employ- 
ment relations. Labour movement pressure groups such as the Institute of Employment Rights and research bodies such as the Labour Research Department have argued that the collectivity of employment law changes, in conjunction with recession and stagnant living standards, represent a major attack on the position and rights of UK workers (see e.g. Labour Research Department, 2013, 13-19). An ideological approach would suggest the pursuit of a largely predetermined agenda, a lukewarm official stance towards public consultation and contradictory evidence, and disproportionate responsiveness towards favoured sources at the expense of others. These have indeed been much-noted aspects of coalition policy-making, highlighted for example in critiques of the welfare reform programme (Slater, forthcoming), the Beecroft Report on employment law commissioned by David Cameron (Jameson, 2012), the Löfstedt Report into health and safety regulation (James, Tombs and Whyte, 2013), and in the House of Lords' Secondary Legislation Scrutiny Committee's inquiry into government consultation procedures (Glenister, 2013). As we will also discuss below, the policy agenda has been marked by a disproportionate reliance on the real or presumed views of business and sometimes, as in the notorious Beecroft case, the views of unrepresentative individual business leaders, a preference for media-friendly anecdote rather than systematic evidence and agenda-framing around heavily ideologically-laden terminology, such as 'burdens on business' and 'red tape'.

On the other hand, one might argue that policy change has actually been gradual, although one would have to discount the significance of increasing use of secondary legislation - a characteristic of all recent governments - in the process. Any primary legal changes affecting employment relations have only really come to fruition by 2013 as minor parts of more general legislation: specifically, that year's Enterprise and Regulatory Reform Act (ERRA), the Growth and Infrastructure Act, as well as the Deregulation Bill passing through Parliament at the time of writing.

Significantly, much of the change to the nature and content of employment relations is also being predominantly achieved through an indirect approach. Employment relations institutions such as the Low Pay Commission, Gangmasters' Licensing Authority and, particularly, the EHRC and the Health and Safety Executive have been affected by cuts to their funding and, in the cases of the last three, their functions too. In the case of the Low Pay Commission, the relative value of the national minimum wage (NMW) has continued to decline in real value under the Coalition, although this process began when the recession hit the UK in 2008. The changes to the employment tribunal (ET) system introduced 


\section{P. Scott and S. Williams: The Coalition Government and Employment Relations}

by the 2013 ERRA weaken the means whereby remaining individual employment rights can be effectively enforced through various mechanisms. These include the introduction of advance fees payable by claimants taking cases to ETs and greater freedoms for employers to influence the pre-tribunal progress of individual employment disputes, through devices such as so-called settlement agreements, which are likely to reduce the number of cases proceeding to tribunal. As with other reforms to restrict access to the justice system, the ET changes in particular highlight what Mangan (2013, 409) describes as the Coalition's remarkable: 'ambivalence regarding rights. These reforms... emphasise the use of law as a tool for economic stimulation rather than a source of rights protection.' In other words, the rationale for employment law is being recast as a prop for employment generation and employer's autonomy rather than a guarantour of universally enforceable rights. The Government's employer - shareholder scheme, under which workers relinquish certain employment rights in return for shares in the company, and the attempt to exempt smaller businesses from certain employment laws are indicative of this conditional approach to the concept of justice.

In collective employment relations, the conditions conducive to trade unions retaining their bargaining role and strength, especially in the public sector, are being undermined by various initiatives, including a number of restrictions on public employers 'subsidising' trade union officials' performance of their duties. Such moves occurred under the tutelage of Conservative ministers responsible for the civil service and local government at a relatively early stage of the Coalition, whereas in schools a consultation on trade union facility time was launched in September 2013, led by Liberal Democrat schools minister David Laws (see LRD Fact Service 38, 25.9.13.). Following a trend established under both recent Conservative and Labour administrations, increased use of what are effectively new providers of state services allows unions' influence to be gradually undermined, partly through the localisation of bargaining in such providers. Such quasi-state institutions include Academy and 'free' schools, and Foundation hospitals in the National Health Service, none of which are required to follow nationally-determined pay scales and rates. In addition, there is increasing use of third and private sector providers, including private prisons, probation and security provision.

A 'gradualist' thesis would also draw attention to the relatively low profile of any real sign of a direct confrontation with unions, in contrast to earlier Conservative governments. Few such developments were noticeable in the first half of the Coalition Government, but the second half has been characterised by an increase in anti-union rhetoric and activity. Part III of the controversial Transparency of Lobbying, Nonparty Campaigning and Trade Union Administration Bill, published in 
July 2013, proposes to place additional state regulation on oversight of trade unions' membership lists, which intensifies a theme initiated by the 1979-97 Conservative Government. Further developments within this theme have revealed the nature of differentiation between the Coalition partners in policies towards collective employment relations. First, proposals for new Conservative policies to weaken unions discussed around the Conservative 2013 Party Conference (Murphy, 2013) indicate: a) a difference of emphasis within the Coalition parties, with Conservative MPs keen to return to more traditional territory; b) the influence of proposals from bodies such as Policy Exchange and the Taxpayers' Alliance to limit trade union freedoms further; and c) opening up of the cracks inherent in Labour legislation, notably by proposals to increase the thresholds on workforce turnout for union recognition ballots to be considered valid that were introduced in Labour's 1999 Employment Relations Act.

Second, in the wake of the complex and acrimonious Grangemouth refinery dispute, David Cameron announced on the $17^{\text {th }}$ November 2013 - a Sunday, strangely - an Inquiry by Bruce Carr QC into the law on trade unions and industrial relations. This revealed different views between the Coalition parties about the appropriate terms of reference of such a review and concern that its timing was designed to resurrect a traditional Conservative theme in the run-up to the 2015 general election (http://www.bbc.co.uk/news/uk-politics-24976760). The terms of reference of this inquiry are mainly directed at alleged misbehaviour in industrial disputes by trade unions. However, the inquiry's brief is also somewhat eclectic, doubtless in deference to Liberal Democrat sensitivities about being seen to address employers' wider, possibly questionable, practices, such as 'blacklisting' of active trade unionists. Nevertheless, it is notable that the inquiry exemplifies the acquiescence in employer-led voluntarism that, as we argue further below, characterises the Coalition's approach to employment relations. The actions of the Grangemouth employer, the private equity firm Ineos, in effectively imposing inferior terms and conditions on a reduced workforce under the active threat of total closure of Scotland's sole refinery, which one can clearly classify as nationally-sensitive infrastructure, do not appear to feature as a major focus of the inquiry.

Supporting a thesis of a gradualist, tentative approach, we should note the Coalition's preference to encourage a voluntary approach by employers, rather than legal compulsion by government, to a wide range of employment relations matters. In this, it follows a path set by Labour's preference for 'light-touch' regulation of certain aspects of employment relations, such as the Blair's government's introduction for 


\section{P. Scott and S. Williams: The Coalition Government and Employment Relations}

some parents of a right to request flexible working from their employer. A number of positive rights connected to the topic of work-life balance have been announced, consistent with a social liberal approach to employment relations (cf. Hepple, 2013), several of which are in the 2013 Children and Families Bill. Such policies include shared parental leave and pay, and the extension to all employees of the 'right to request' flexible working. It should be noted that, in some cases, employers have a right to refuse requests for business reasons. Other aspects of employerled voluntarism suggest the likelihood that some rights may be diluted for exigencies of business. These include important aspects of occupational health and safety provision, equal pay audits and equality (cf. the critical observations of the House of Commons Business, Innovation and Skills Committee, 2013) HoC BIS Ctte Report 2013-14 Women in the Workplace, HC342, vol 1).

A further interesting aspect of government's preference to exhort positive employer practice than to enforce it through statue can be found in the case of current debates in the UK about the concept of paying a so-called 'Living Wage' set at a higher level than the NMW. The idea of a Living Wage has been endorsed by figures in most political parties, and notably by David Cameron and London Mayor Boris Johnson (Pyper and Davies, 2013, 4-7). Crucially, however, we would argue, its voluntary nature enables Coalition ministers to endorse the idea at little political cost while relinquishing to individual employers any responsibility for implementing it. Clearly, the relative decline in the level of the NMW suggests little political commitment to using state power to improve living standards at the lower end of the labour market, which is now an increasing political issue in the UK (Resolution Foundation, 2013).

\section{The (selective) rhetorics of change}

Essentially, the Coalition has deployed a number of rhetorics to justify its programme of changes to employment relations. Some of these claim to be arguments of externally-driven necessity, while others exemplify the uneasy tension between market fundamentalist liberalism and social liberal values within the Coalition (Hepple, 2013), where the former is nevertheless normally in the ascendant. The main strands can be identified as the compulsion of 'new' globalisation, the virtue of deregulation, work as a duty, the exigencies of crisis, a more general and permanent narrative of state failure that has emerged out the 'crisis' rhetoric, and a slippery notion of 'fairness'. We discuss these briefly in turn. 
First, the changing nature of globalisation and the impact of Asiandriven entrepreneurial capitalism on the UK has formed a prominent theme in David Cameron's premiership, exemplified by his leadership of a number of trade missions to countries such as India and China. Essentially, it is argued that the UK needs to learn from the educated, but low cost base and (in some respects) deregulated employment regimes characteristic of these new competitors, who fulfil a function for the Coalition similar to that occupied by expanding Japanese capitalism from the mid-1980s to the mid-1990s. The logic here is to de-emphasise Europe as a comparator for the UK, with its attendant employment model, in favour of emulating a 'small state' style of entrepreneurialism and aspects of its employment-generating employment model. A persistent, if somewhat shrill, influence on Government thinking here has been the ideas of a group of relatively new and small business-friendly Conservative MPs who have coalesced in the so-called Free Enterprise Group, and its 'manifesto' Britannia Unchained (Kwarteng et al., 2012).

Second, it follows from the above that the need for deregulation to eliminate domestically- and European-derived barriers and costs to businesses has formed a key theme in Coalition rhetoric. As suggested above, it is also one of the areas most heavily reliant on myth and populist hyperbole, reinforced particularly by the media and the work of pressure groups such as the Taxpayers' Alliance. Allegedly excessive regulation of employment relations is identified in concerns with health and safety and a preoccupation with eliminating risk, the existence of a 'compensation culture' whereby malevolent and calculating employees seek to exploit regulative avenues to seek redress against hapless employers for real or imagined wrongs, and the prohibitive cost of employment regulation as a barrier to a more flexible labour market. It is such rhetoric that explains the Coalition's focus on reducing employment rights connected to performance and dismissal (such as settlement agreements; reductions in the qualifying period for being able to claim unfair dismissal; and the length of consultation periods in the event of collective redundancies; or the relinquishment of certain employment rights in return for 'employee-shareholder' status); the distaste for active state-sponsored promotion of equality through such means as equality impact assessments; and greater voluntarism in health and safety. One striking feature of the Coalition - although also reminiscent of the outlook that developed from the mid-Thatcher years of government departments responsible for business and employment - is the extent to which this ideological terminology has been explicitly imported into official discourse and policy initiatives, such as the Red Tape Challenge, initiated in April 2011. This is best viewed as a faux-democratic on-line 
crowd-sourcing exercise, the purpose of which is to help 'free up business and society from the burden of excessive regulation' (www.redtapechallenge.cabinetoffice.gov.uk/home/index). To this end, the general public is invited to discuss the value of existing regulations, which are listed where relevant, and whether or not they are deemed desirable, or should be reformed or revoked. In the 2011-12 period, the focus of the RTC turned to employment regulation, acting as 'an additional lens through which to view the obligations on businesses in employing people, by focusing on specific regulations' (Department of Business, Innovation and Skills, 2012, 5). Again, this suggests the enrolment of views of unknown representativeness and robustness and indeed- mere anecdotal evidence in the formulation of government policy. It is unsurprising that commentators (e.g. Hepple, 2013, 213-217) have noted the flimsy evidence base on which assertions of the relative over-regulation of employment in the UK, business perceptions about the reality of employment law and the rationale for its current reform rests, as well as the reality of declining payouts for health and safety breaches (O’Neill, 2013).

Third, a narrative of work is deployed, which subtly elides two notions of it (Budd, 2011): work is promoted as a means of gaining freedom and personal independence, including independence from the state, while, for those inactive in paid labour, work is regarded as a form of service to the community on which the receipt of transfer payments should be conditional. This both delegitimises the concerns of those not in work and the relative importance attached in public policy debate to wage levels and other measures of job quality embodied in the post-war settlement. This creates a gulf between the interests of the working and the workless, with evidence suggesting that social attitudes towards the latter group have hardened under the Coalition (Clery, Lee and Kunz, 2013).

Fourth, a narrative of 'crisis' has been deployed to justify rapid change in certain spheres, most notably that of public sector reform. As in previous instances, such as the 1978-79 'Winter of Discontent' (Hay, 1996), a sense exists whereby the exigency of crisis has been exploited in order to achieve changes that might not be regarded as acceptable in other political circumstances. In this case, the UK's chronic dependence on a model of financial capitalism seen to fail so spectacularly in the crisis from 2007 has led, not to a questioning of neo-liberalism, but its reassertion through the redefinition of a consequence of the crisis (high levels of public borrowing and state deficit)as its cause (cf. Mirowski, 2013).

Fifth, the notion of crisis as the midwife of restructuring has evolved into a longer-standing neo-liberal refrain, that of state failure. This has laid the ground for what may well actually be a longer-term 
policy of reducing government intervention in certain areas of employment policy and for radical public sector reform, on a classic Hayekian New Right narrative of the unresponsive and bloated state. Such a shift was signalled in Cameron's 'Lord Mayor's' speech in November 2013 (Kettle, 2013), which contrast markedly with the former espousal of 'compassionate Conservatism'. This theme is evident in, for example, the curtailment of certain state functions in employment relations, such as the abolition of the AWB, reduction of the EHRC and HSE, and the campaign by Conservative-aligned pressure groups such as the TPA and the Trade Union Reform Campaign on state support for trade union functions such as facility time. Judicious exploitation of examples of past state 'failures' that can be laid at the door of the previous Labour mode of public service management, such as the case of the MidStaffordshire NHS Trust, have helped considerably here.

Finally, however, the Coalition has faced a particular need to publicly justify the nature of employment policies being pursued, not least because of the government's apparent social unrepresentativeness and the multiple widening inequalities within the UK labour market that have become increasingly evident over recent years. Recalling past episodes of austerity from the twentieth century, there has been a perceived need to invoke some concept of equity of sacrifice. To this end, a nebulous rhetoric of 'fairness' has been deployed to improve the palatability of the changes proposed. As Hepple's (2013) analysis also suggests, this notion tries to encompass two very different conceptions of the term within the Coalition, and the usage of the term 'fairness' might be considered sufficiently elastic in practice as to be close to breaking point. Some deployments of the term have been in deference to the residual social liberalism in the Liberal Democrat side of the Coalition. Its use in relation to the limited extension of policies designed to improve worklife balance, shared parental duties, and to extend the ability to work flexibly has been noted above. It is also perhaps significant that a greater emphasis on even-handedness between 'both sides of industry' characterised Liberal Democrat reactions both to the Beecroft proposals and to the proposed terms of reference of the Carr Inquiry (see above) (BBC News, 2013). In view of the Coalition's attempt to shrink the state sector, it is significant that practices in the relatively deregulated and weakly unionised - non-financial - private sector have been co-opted as a benchmark for what constitutes 'fairness'. Thus, public sector employment practices are castigated as unjustifiably generous compared to those in the private sector, which currently comprises just over $80 \%$ of total UK employment. Such logic informed an early stage of the Coalition's intervention into employment relations, when it asked Will Hut- 
ton to look at the 'fairness' of top pay in the public sector. The limits of such logic was swiftly revealed in Hutton's (2010) interim report, which revealed the far greater pay dispersion and levels of executive pay evident in the private sector relative to the public sector.

\section{Evaluating the politics of change}

Overall, we would argue that the overall trajectory of change is uneven progress towards radical reform of employment relations by a oneterm government in a hurry. Two policy themes can be highlighted: distancing the responsibility of the state as a guarantour of employment relations in favour of increased reliance on, first, enforcement by increasingly disempowered individuals of the remaining corpus of employment rights and, second, the voluntary initiatives of employers. Ordered industrial relations, and the ability to exercise individual and collective employment rights are stealthily eroded and rendered more dependent on the goodwill of the human resource strategies of 'enlightened' employers.

While some employment rights and protections are being removed, the more dominant and concerning long-term trend is the deracination of those that remain, primarily through weakening the available individual and collective means for, and effectiveness of, their enforcement, and the further strengthening of employers' hand in dealing with employees, through such devices as settlement agreements and the introduction of a 'public interest' clause to reduce the circumstances in which 'whistleblowing' is legally protected. Hence we liken the UK's employment relations framework to a colander: increasing numbers of holes in the system empty it of much of its meaningful content. Evidence suggests that the UK's 'individual rights' model was already an inadequate tool for satisfactory enforcement in the context of declining union density (Dickens, 2012; Pollert, 2007; Pollert and Smith, 2009), and the ET system has become increasingly structurally ill-suited to the achievement of employment justice (Corby and Latreille, 2012). UK workers were confronted with considerable legal, financial and other barriers to pursuing redress through the ET system, even before the Coalition's reforms (Renton, 2012). However, Government-commissioned research suggests that one third of those workers who do win at ET fail to get financial compensation because the guilty employer refuses to pay (IFF Research, 2013). Taylor's (2013) research on the pervasive abuse of performance management techniques in some companies suggests their strategic manipulation of 'low performing' employees to ensure that it is the employee, rather than the employer, who initiates the request to exit the 
organisation. In such circumstances, employees' alleged legal protections against employers count for little. It is in this context of the further gradual weakening of employment legislation and the ability to enforce it that the Coalition's narrative of over-regulation rings particularly hollow. The balance of policy so far suggests more of a stress on weakening existing workers' rights than generating new employment (e.g. unfair dismissal qualifying period, foreshortening redundancy consultation period), other than through hoping to create indirectly the economic conditions believed to generate it.

Government claims its support for employer-led good practice in aspirational positive employment and sophisticated human resource policies, such as the Living Wage, equal pay, non-discrimination, and extensive consultation. However, by atrophying the available means of legal enforcement it absolves itself of responsibility relative to individual employers for the adoption by business of such policies. Essentially, such positive policies are recast as conditional, subject to employers' affordability and goodwill. In practice, many employers under the financialised form of capitalism dominant in the UK (Thompson, 2011) and within restrictive supply chains are likely to find it very difficult to deliver positive employment policies, without the kind of state intervention from which the Coalition is retreating. In such a deregulated environment, the much-remarked rise of agency workers, zero-hours contracts, internships and other forms of precarious employment and underemployment since the recession becomes easier to understand.

Employment reforms to date have produced relatively little overt dissent within the Coalition. In one sense, this should not surprise us, given the uneven ideological coalescence of the main UK political parties since the 1990s around the major tenets of neo-liberalism, as paralleled elsewhere in Europe (cf. Baccaro and Howell, 2011). Indeed, in comparison to Labour's partial reinstitutionalisation of ER, few ideological differences have been visible between the two Coalition parties on ER matters (Bach and Kessler, 2011; Williams and Scott, 2011) prior to the pre-election positioning in relation to trade unions (discussed above) evident at the time of writing. Also, much overt employment relations change has affected the restructuring of the public sector disproportionately. Public sector reform tends to have been driven from departments headed up by Conservatives, notably the Cabinet Office, the Department of Communities and Local Government, the Ministry of Justice, and the Department of Health. Even where Liberal Democrats are in ministerial positions in departments with Conservative Secretaries of State, such as Schools Minister David Laws under Michael Gove's De- 
partment for Education, there seems to be little difference in policy emphasis.

The UK is in the unusual position by European standards of having had no dedicated ministry for labour-related issues since 1995. Instructively, employment relations have been relegated increasingly to subsidiary concerns within the remit of those departments of government whose primary responsibility is business and industry. Formally, ER is a minor part of a portfolio of Liberal Democrat responsibilities in the Department of Business, Innovation and Skills, under the tutelage of Secretary of State Vince Cable and his Under-secretary of State for Employment Relations, Consumer and Postal Affairs, Jo Swinson. Meanwhile, responsibility for equalities issues has been shuffled around government and, oddly, now falls under the remit of a Conservative minister in the Department of Culture, Media and Sport. With few exceptions, such as over the Beecroft Report and to a minimal extent over the relative devaluation of the NMW since 2008, dissent has tended to come from the Coalition's wider parliamentary parties or their parties in the country as a whole. However, this quiescence is unlikely to continue, especially as the Coalition parties have begun to differentiate their policies in their attempts to position themselves for the 2015 general election. Whereas some LDs like Cable have been keener to emphasise in a relatively low-key way the avoidance of 'abuses', such as with zero hours contracts, the Conservative Party has been keener to return - somewhat unconvincingly and partially for reasons of perceived electoral advantage, given the dominance of Unite as a trade union and funder of the main opposition party - to the traditional theme of the need for further restrictions of collective employment relations.

In theory, the issue of EU-derived employment rights should have provided the largest potential cause of dissension on employment issues within the Coalition. However, conflict has largely been deferred until after the present Coalition's tenure ends in 2015. Even here, the EU's recent turn towards neo-liberalism, evident in the troika-driven state bailouts, programmes of austerity and public sector reform, and the tenor of some judgments emanating from the European Court of Justice weakening workers' rights, have helped to dilute Europe as a 'problem' for the Coalition (at least in this respect). Both sides of the Coalition have rejected the writing of additional restrictions into EU Directives when transposed into UK law: so-called 'gold-plating'. 


\section{Conclusions and prospects}

It may be too early, after three and a half years, to judge how successful, or far-reaching the effects of, the Coalition's employment reforms will be. However, the direction of travel is clear, and it looks somewhat unlikely - given the volatility of current electoral politics, coupled with the inability of any political party to form a decisive electoral lead - that the 2015 General Election will significantly change the pattern of developments analysed above. It is clear that employment creation has not suffered under the Coalition, despite the parallel persistence of levels of unemployment that would have been regarded as politically unacceptable two generations ago. However, our concern is with the condition of the dominant types of employment that are being created and the gradual erosion of UK workers' ability to exercise employment rights and 'industrial citizenship' on terms other than those granted by employers.

Given the continued, and perhaps surprising, persistence of neoliberal narratives within the Westminster political establishment and its parties, the outlook is relatively bleak. Public resentment about low pay, the decline in the real value of take-home pay, job insecurity and the quality of public services that are increasingly subject to cuts and charges is palpable, but it is fragmented and weakly coordinated. Employment regulation will loom large in the debates about the UK's place within the European Union that will follow the 2015 election, but the question is to what extent this will be framed within the nationalist and semiPoujadist rhetoric that appears to dominate the United Kingdom Independence Party, much of the Conservative Party and the print media.

It is important to recognise that increasing divergences have opened up between Coalition-dominated England and the devolved governments in the rest of the UK, where the Coalition parties do not hold sway, in public sector policies and employment practices. This has resulted in different policy directions to some of the goals pursued in England. In Wales, Scotland and Northern Ireland greater value has been attached to: tripartism between devolved government, trade unions and employers; public sector equality duties; promoting positive employment practice when awarding government contracts; preserving the codes of practice that guard against the emergence of a 'two-tier' workforce in public contracts, safeguarding the mechanisms to protect agricultural wages; and so on.

However, the main elements of the employment relations repertoire remain under the control of the Westminster government, as does the block funding for the devolved territories. We have argued that the Coa- 
P. Scott and S. Williams: The Coalition Government and Employment Relations

lition is attempting to unpick important aspects of the post-war settlement for industrial relations with the intention of extending further the flexibility and vulnerability of the UK workforce, while professing the retention of an -unspecified - core of employment rights. We have shown that many of the Coalition's reforms make more conditional on employees' affordability, on employers' goodwill, and on the decreasing likelihood of union representation the exercise of whatever rights remain. This is not so much the 'modernisation' of employment relations as a collective enterprise as the 'hollowing out' of employment relations.

\section{Bibliography}

Baccaro, L. and Howell, C. (2011) A common neoliberal trajectory: the transformation of industrial relations in advanced capitalism, Politics and Society, 39, 4, 521-563.

Bach, S. and Kessler, I. (2011) The Modernisation of the Public Services and Employee Relations: Targeted Change, Basingstoke, Palgrave Macmillan.

Bach, S. and Stroleny, A. (2013) Public service employment restructuring in the crisis in the UK and Ireland: social partnership in retreat, European Journal of Industrial Relations, 19, 4, 341-357.

BBC News (2013) Union 'intimidation' tactics probed in disputes inquiry, $B B C$ News, 17 November, London, BBC, http://www.bbc.co.uk/news/uk-politics-24976760.

Budd, J. (2011) The Thought of Work, Ithaca, NY, ILR Press.

Clery, E. Lee, L. and Kunz, S. (2013) Public Attitudes to Poverty and Welfare, 1983-2011, London, NatCen Social Research.

Corby, S. and Latreille, P. (2012) Employment tribunals and the civil courts: isomorphism exemplified, Industrial Law Journal, 41, 4, 387406.

Department for Business, Innovation and Skills (BIS) (2012) Employment Law Review. Annual Update 2012, London, BIS.

Department for Education (2013) Reviewing and revising a school's approach to teachers' pay, London: Department for Education, http://www.education.gov.uk/schools/careers/payandpensions/te acherspayandconditionsdocument/f00224072/review-teacher-pay.

Dickens, L. (ed.) (2012) Making Employment Rights Effective: Issues of Enforcement and Compliance, Oxford, Hart Publishing.

Glenister, S. (2013) Lies, farce and obfuscation: the government's new approach to consultation, 13 March, Liverpool, Institute of Em- 
ployment Rights, http://www.ier.org.uk/blog/lies-farce-andobfuscation-governments-new-approach-consultation.

Grimshaw, D. and Rubery, J. (2012) The end of the UK's liberal collectivist social model? The implications of the coalition government's policy during the austerity crisis, Cambridge Journal of Economics, 36, 1, 105-126.

Hay, C. (1996) Narrating Crisis: The Discursive Construction of the 'Winter of Discontent', Sociology, 30, 2, 253-277.

Hepple, B. (2013) (2013) Back to the Future: Employment Law under the Coalition, Industrial Law Journal, 42, 3, 203-223.

House of Commons Business, Innovation and Skills Committee (2013) Women in the Workplace, First Report of Session 2013-14, HC342, vol. 1, London, The Stationery Office.

Howell, C. (2005) Trade Unions and the State: The Construction of Industrial Relations Institutions in Britain, 1890-2000, Princeton, NJ, Princeton University Press.

Hutton, W. (2010) Hutton Review of Fair Pay in the Public Sector: Interim Report, London, HM Treasury.

IFF Research (2013) Payment of Tribunal Awards 2013 Study, London, IFF Research.

James, P., Tombs, S. and Whyte, D. (2013) An independent review of British health and safety regulation? From common sense to nonsense, Policy Studies, 34, 1, 36-52.

Jameson, H. (2012) The Beecroft Report: pandering to popular perceptions of over-regulation, Political Quarterly, 83, 4, 838-843.

Kettle, M. (2013) The moment David Cameron lost the 2015 general election, The Guardian, 14 November, http://www.theguardian.com/commentisfree/2013/nov/13/david -cameron-permanent-austerity-lose-election-2015.

Kwarteng, K. et al. (2012) Britannia Unchained, Basingstoke, Palgrave.

Labour Research (2013) TUPE proposals attack terms and conditions, Labour Research, 102, 12, 21.

Labour Research Department (2013) Law at Work 2013, London, Labour Research Department.

Mangan, D. (2013) Employment tribunal reforms to boost the economy, Industrial Law Journal, 42, 4, 409-421. 
P. Scott and S. Williams: The Coalition Government and Employment Relations

Mirowski, P. (2013) Never Let a Serious Crisis Go to Waste: How Neoliberalism Survived the Financial Meltdown, London, Verso.

Murphy, J. (2013) Crackdown on trade union powers and perks to be unveiled at Tory Party conference, London Evening Standard, 27 September, http://www.standard.co.uk/news/politics/crackdown-ontrade-union-powers-and-perks-to-be-unveiled-at-tory-partyconference-8843987.html.

O’Neill, R. (2013) Robbed, Hazards, no. 122, www.hazards.org/votetodie/robbed.htm.

Pollert, A. (2007) Britain and individual employment rights: 'Paper tigers, fierce in appearance but missing in tooth and claw', Economic and Industrial Democracy, 28, 1, 110-139.

Pollert, A. and Smith, P. (2009) The limits of individual employment rights: The reality of neoliberalism, in Blanpain, R., Bromwich, W., Rymkevich, O. and Spattini, S., (eds.) The Modernization of Labour Law and Industrial Relations in a Comparative Perspective. Alphen aan den Rijn, Kluwer Law International BV., 113-132.

Pyper, D. and Davies, J.M. (2013) The Living Wage, House of Commons Library, Standard Note SN06675, 22 July, London, House of Commons Library.

Renton, D. (2012) Struck Out; why employment tribunals fail workers and what can be done, London, Pluto Press.

Resolution Foundation (2013) Low Pay Britain 2013, London, The Resolution Foundation.

Slater, T. (forthcoming) The myth of 'Broken Britain': welfare reform and the production of ignorance, Antipode, forthcoming.

Taylor, P. (2013) Performance Management and the New Workplace Tyranny, report for the Scottish Trades Union Congress, Glasgow, University of Strathclyde.

Thompson, P. (2011) The trouble with HRM, Human Resource Management Journal, 21, 4, 355-367.

Williams, S. and Scott, P. (2010) 'Shooting the past? The modernisation of Conservative Party employment relations policy under David Cameron', Industrial Relations Journal, 41, 1, 4-18.

Williams, S. and Scott, P. (2011) 'The contingent basis of Conservative Party modernisation under David Cameron: the trajectory of employment relations policy', Parliamentary Affairs, 54, 3, 513-529. 